\title{
鋳込特性の動的測定についで
}

\author{
沢井郁太郎** 梅 屋 薰***西川友三**** 川本 晋****
}

\section{On the Dynamic Measurement of the Casting Process}

\section{Ikutarō Sawai, Kaoru Umeya, Tomozō Nishikawa and Susumu Kawamoto}

Constructing an apparatus being similar to that of Ferry and his co-wcrkers which was used for measuring the dynamic properties of some hypolymers, the changes in dynamic viscosity and dynamic rigidity during the casting of clay slips for refractory crusibles were measured.

It was found out that the casting properties were affected by

(1) the distance from the mold surface,

(2) the amount of defloculant, and

(3) the quality of the defloculating electrolyte.

\section{1. 緒㝘}

鋳込とは䈘業の分野で用いられる成形法の一種であ

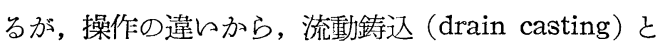
固形慗込 (solid casting) と飞分けられる. 流動鋳込 では，原料は流動性を本質として持つている泥漿であ つて, 鋳込操作の途中で脱水を行つて, 士芏の状態と

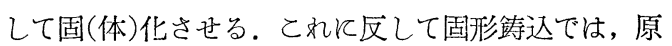
料は本質的淔体である坏土であつて, 䣄込に際して は, 摇変性といわれているコロイド代学的挙動によつ て流動化させる。

このように流動鋳込では, 用いる泥漿の濃度が比較 的薄くて流動性を持つているので, 鋳型 (mold) 中に 注的で時，よく鋳型の隅々まで详するととができる。 鋳型としては，石高交に゙のように吸水性のある材質の ものを撰び, 注加された泥漿中の水分は鋳型の材質に 吸われ, 脱水を受ける.脱水と已もに鋳型の壁面飞鋳 込体が形成される。一定時間経過して, 鋳込体の厚さ が所期の厚さとなつそとき, 鋳型を傾けて残存泥漿を 排出し, 次いで鋳込体をとり出す.

固形鋳込に用的る泥漿は高濃度であるので, そのま まの状態では, 流動して鋳型の隅々まで達するととは でをない. 流動伦は thixotropy あるいは false body といわれている摇変挙動によつて与えられる。すなわ ち泥漿自身を, あるいは鋳犁を, あるいは泥漿と鋳型 を相方とも, 外部より, 主として機饿的な力を加完て振 動なり摇動なりさせて, 泥漿の見掛の粘性を一時的飞 低下させて流動化させる，外力を印加するのを中止す ると, 粘性は元に復つて粘稠なものになるので, この

\begin{tabular}{|c|c|}
\hline$*$ & 原檍受付 昭和 30 年 5 月 31 日 \\
\hline$* * *$ & 正員＼cjkstart京都大学工学部 \\
\hline$* * *$ & 正員 景都大学化学研究所 \\
\hline$* * * *$ & 正員 京都大学化学砄究所 \\
\hline
\end{tabular}

昭利30年 9 月
場合の鋳型の材質は吸水性であるととを必要条件とし ない. まを固化は内容物全体にわたつて起とるので, 鋳込体と残存泥漿とには分かれない. 流動鋳込が薄手 の器物で, 主として内部飞空孔部のあるものを作るに 利用されるに反して, 固形鋳达は中空部を持をな的 手の器物の成形に利用される。

このようと鋳込は, 原料である泥遙の流動性と, 製 品である鋳込体の硕さが支配的宗性質となつている。 泥漿の流動性が小さいと, 複雑な型の隅々まで達する ことができないので，形を作る性質（造形性と呼ぶこ とにする）が劣化する。㤽込体の硬さが小さいと, 脱 型後切角造形した形を重力に抗して崩さずに保つとと ができない(保形能と呼ぶととにする). 従来行われて レる考察では, 造形能は泥漿の炶性(流動性の逆数) 飞 より, 保形能々鋳込体(坏土)の降伏值によつて測定し, かつ, これらの值は毛管粘度計か, 共軸延転粘度馀,

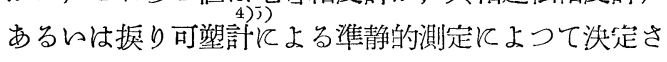
れを值を基にして考察を進めをすのである。

鋳込とは，流動性のある泥漿か流動度を失つて硬さ を増し，坏土となる過程であるので，鋳込特性として は, 粘土の水々対する瞅濁体である泥漿一坏土系の粘 弾, あるいは塑弹特性の時間的経過を追求することで ある。乙のようと時間飞敏感な特性の時間的経過を測 定するととであるので，一定小容量の試料を採集し， て, 準静的《測定するののみでは充分でない.

Woodward 5 浡 vibrating reed を用的, 共振法 で懸濁液の粘度を測るととを提案し,その応用として, “powdered iron” の流動鋳込, artware の流動鋳込 なぞの鋳込特性の時間的変動を測定し, 鋳型中の位置 による変動, 解埲剂の量による影響などについての考 察を行つた。乙の場合, 装置の特質から, 鋳达特性は 
(粘性 $) \times($ 密度 $)=(\eta \rho)$ で示された。

鋳込体は高濃度の懸濁体であるので, そのコロイド 化学的な挙動は複雑であつて, thixotropy あるいは false body 的などの挙動を考えなけ礼ばならす， ク

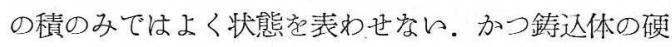

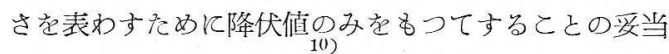

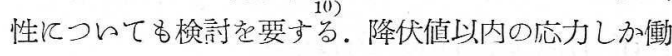
かないとてても, 坏土の弾性係数が小さければ変形は 大きい．㟐土の弾性係数は他の物質に比べて小さいの で, この弾性限界内の変形も, 精密子造形に刘しては 考慮起要する。たと乞淘磁器などの薄物鋳込で，素 地のてれと称して娽つている現象は, 塑性流動以外に Hook 領域での変形る加味されていると推定される。

筆者らは，Ferry らか用的を軸方向を振動方向とす る共軸円筒型啙度計を用々て，鋳込特性の動的測定に 当つそ。当垬告はその結果についての報告である。

Ferry の装置では, 動沾性係数 グの外に動弾性係数 $G^{\prime}$ の值も测定できる。

鋳迀特性の時間的経過を測定するには, reed(Wcodward) 者用いるにしても， rod.(Ferry) t用いるにし ても不つごうなととが起とる。それは reed なり rod なりの一方の侧から固化しそ壁が近づき, その面から 固化が進行する。したがつて固化の途中では, 粘度計 で測れる粘弾性係数は厳密なものではない.

動弾性係数を準静的に測定されそ弾性係数と比較す るには幾多の疑問が存在する. 動的弾性係数の測定値 から鋳込操作中の硬さの変動について諭ずるのは，椧 討要要する余地が多い. しかし，とにかくFerryの装 置加ら得られる動弾性係数乙動阽性係数の時間的変化 の測定値老基礎として鋳込特性の考察走行つてみえい と思う。

\section{2. 測定装置ならびに理論的根极}

測定装置はFerryらによつて用いられた装置と同型 式のものと乙, 共軸円筒浸大型 (ccaxial penetration type) の測定部分を持つ てレる(Fig. 1). $\operatorname{rod} の 上$. 部に可動線輪 (Fig. 2. A) があつて，A は固定永久 磁石Bの磁場内の定位置

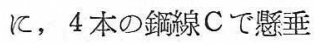
されている.可動線輪を 交流 bridge $\left(\mathrm{D}_{1}, \mathrm{D}_{2}, \mathrm{D}_{3}\right.$, $\mathrm{D}_{4}$-Fig. 3) の一要素と 乙て, 周波数領域 $40 \sim 200$ 巴発発信器(Fig. 3, E) 凤 より導入さす. $\mathrm{D}_{2}$ の端 子電圧老真空管電圧計 $\mathrm{F}$ で測定して大力電流を一

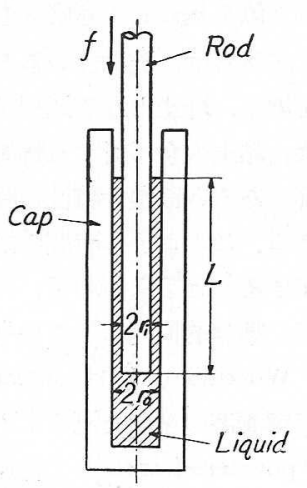

Fig. 1. Measuring part of the coaxial penetration type viscometer.

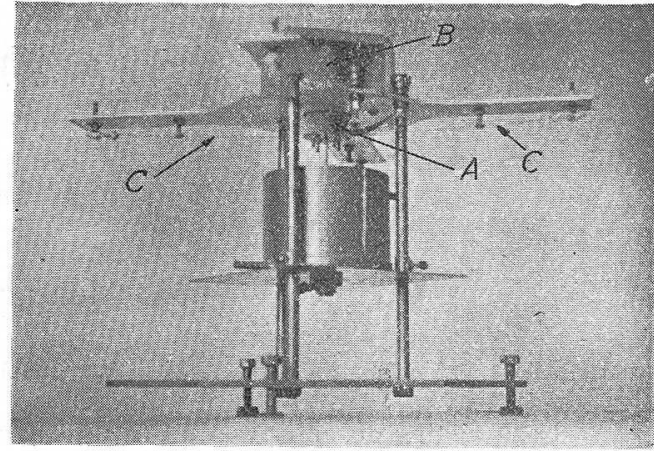

Fig. 2. Vibration viscometer

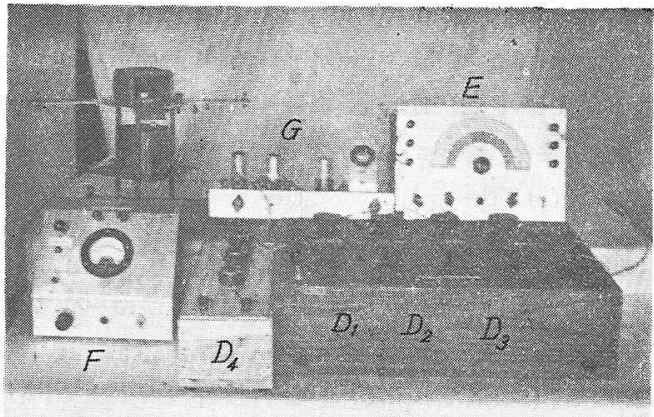

Fig. 3. Measuring system.

定とする。G補償回路の電圧計である。

共軸口筒浸入型の粘度計については, Ferry の外に Bikermann, Pattersen, Markovitz, 堀尾, 小野木両 氏によつて取扱われ，それらの結果によると，検液の mechanical resistance $R_{M}$ は

$$
R_{M}=\frac{f}{v_{i}}=\frac{2 \pi \eta L \frac{\left(r_{u}^{2}+r_{i}^{2}\right)}{\left(r_{a}^{2}-r_{i}^{2}\right)}}{\frac{\left(r_{a}^{2}+r_{i}^{2}\right)}{\left(r_{a}^{2}-r_{i}^{2}\right)} \ln \frac{r_{a}}{r_{i}}-1}=a^{\prime} \eta^{\prime} L
$$

で与えられる。ただし， $v_{i}$ r rodの速度，クは検液の 粘性係数で, 他の值は Fig.1亿示されそものである. ことで $\eta^{\prime}$ 起動粘性係数， $G^{\prime}$ 動弾性係数と称するこ ととする。

$$
\eta^{\prime}=\frac{1}{a^{\prime}} \cdot \frac{R_{M}}{L}, G^{\prime}=-\frac{\omega}{a^{\prime}} \cdot \frac{1}{L}\left(X_{M}-X_{M 0}\right)
$$

にようて決まる[外に参照した文献：(19)(20)]。ここ に $R_{M}$ は検体に対する mechanical resistance, $X_{M}$, $X_{M 0}$ は検体並に空気中での振動に対する mechanical reactance である. $\eta^{\prime}$ も厳密な意味では

$\left(1 / a^{\prime}\right)\left\{\left(R_{M I}-R_{M 0}\right) / L\right\} \quad て ゙$ 表わさるべさであるが， $R_{M 0}$ (空気中での值) は $R_{M}$ (検体中での值) に比べる と無視できるくらい小さい測定值となる。 $R_{M}, R_{M 0}$, $X_{M}, X_{M 0}$ は transducer 回路で

$$
\begin{aligned}
R_{M} & =(B l)^{2} \times 10^{-9}\left(R-R_{0}\right) /\left[\left(R-R_{0}\right)^{2}+\left(X-X_{0}\right)^{2}\right] \\
R_{M 0} & =(B l)^{2} \times 10^{-9}\left(R_{\text {air }}-R_{0}\right) /\left[\left(R_{\text {air }}-R_{0}\right)^{2}\right. \\
& \left.+\left(X_{\text {air }}-X_{0}\right)^{2}\right]
\end{aligned}
$$




$$
\begin{aligned}
X_{M} & =(B l)^{2} \times 10^{-9}\left(X-X_{0}\right) /\left[\left(R-R_{0}\right)^{2}+\left(X-X_{0}\right)^{2}\right] \\
X_{M 0} & =(B l)^{2} \times 10^{-9}\left(X_{\text {- ir }}-R_{0}\right) /\left[\left(R_{\text {‘ir }}-R_{\text {i }}\right)^{2}\right. \\
& \left.+\left(X_{\text {qir }}-X_{0}\right)^{2}\right]
\end{aligned}
$$

より得られる。 $R, X, R_{\text {rir }}, X_{\text {air }}, R_{0}, X_{0}$ はとれ ぞれ検体中，空気中，和よび振動棒を固定したときの electrical impiedance の resistance 部分ならびに reactance 部分である. $(B l)^{2} \times 10^{-9}$ は変換常数であ る.

慣性項が大ると, ( 1 )式の右辺に係数 $(1+i \omega \rho \beta / \eta)$ が掛かる。 $\omega$ は周波数, $\rho$ は検液の密度, $\beta$ は補正項 で, $r_{a}, r_{i}$, ならびに $r$ 函数であるが, 当実験に用 らた $r_{a}=0.24 \mathrm{~cm}, r_{\imath}=0.15 \mathrm{~cm},(L=2 \sim 4 \mathrm{~cm})$ の範囲 では， $\omega \rho \beta / \eta$ の值は 1 亿比べて無視でをるくらい小 さn.

\section{3. 測定結果ならびに考察}

(3) 式中の $R_{\text {air }}, X_{\mathrm{air}}, R_{0}, X_{0}$ の測定值は Fig. 4, Fig. 5 亿示される. 装置の測定範围は, $\gamma^{\prime}$ は 100 $25000 \mathrm{cp}, G^{\prime}$ は $10^{3} \sim 10^{\mathrm{s}} \mathrm{dyne} / \mathrm{cm}^{2}$ である。

常数 $(B l)^{2} \times 10^{-9}$ を決めるには

$$
X_{M 0}=\omega M-\frac{S_{M 0}}{\omega}
$$

による。ただし， $M$ は振動系の可動部分の質量， $S_{M 0}$ は可動部分の支持系統の硬さ (stiffness) から決まる数 值， 領域での $X_{M 0} /(B l) \times 10^{-9}$ と $\omega=2 \pi f$ の関係から決

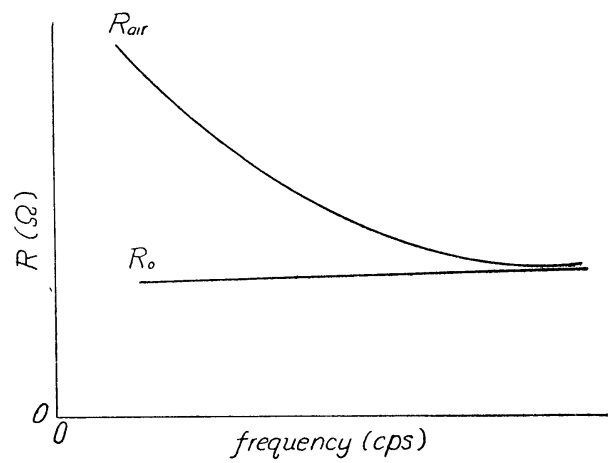

Fig. 4.

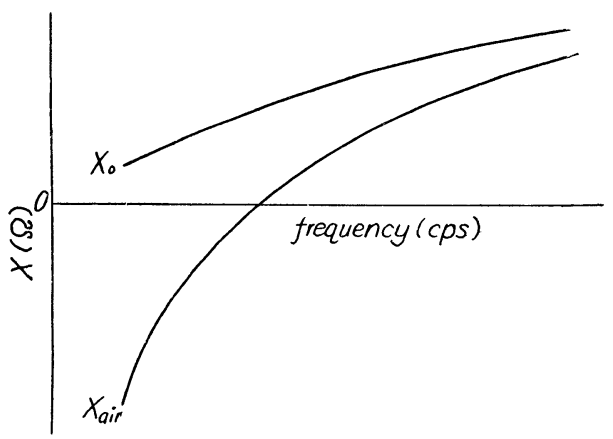

Fig. 5.
められる。とのようにして決定した $(B l)^{2}$ の值を；標 準グリセリン $\left(D_{2 丂^{\circ}}=1 \cdot 255, \eta=550 \mathrm{cp}\right)$ 在用いて補正

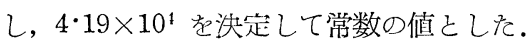

なお，このグリ七リンを碑和周波数低存性を測定 した結果は Fig. 6 であり，40〜150ゃの間は低存性 が存しなら. $G_{1}, G_{2}, G_{3}$ の区別は振動棒の浸漬 $(L)$ の深さによる変化を赤す。更に $L$ に関する

$X_{M} /(B l)^{2} \times 10^{-9}, R_{M} /(B l)^{2} \times 10^{-9}$ の低存性の詳 細を示すと Fig.7 のようとなる。検液はグリセりン であるので, $X_{U} /(B l)^{2} \times 10^{-9} の L$ K関する依存性は

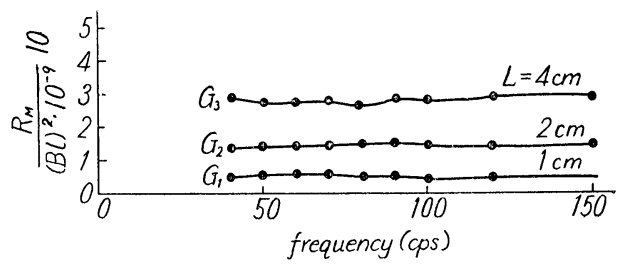

Fig. 6. Frequency dependency for the standard grycerine.

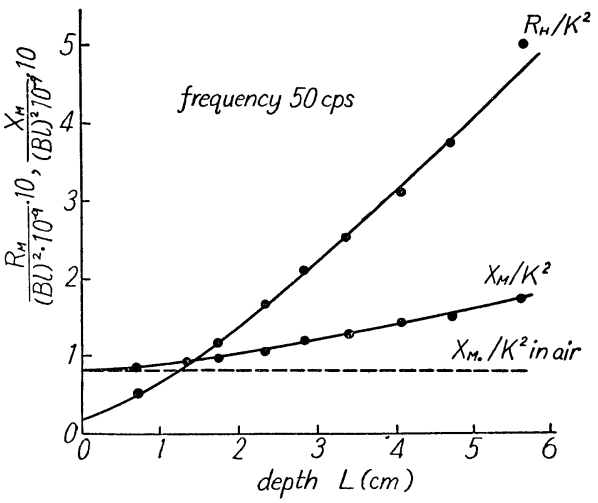

Fig. 7. Dependency for the immersion depth.

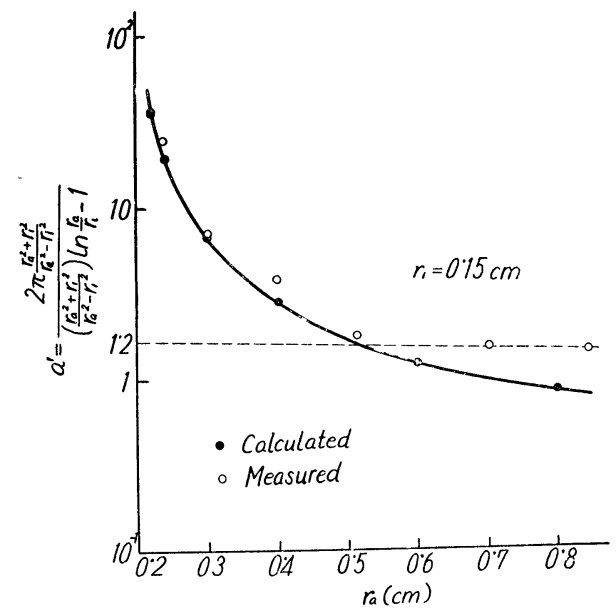

Fig. 8. Relation beiween shape factor $a^{\prime}$ and the cap radius $r_{a}$, 
レわりる mass eflect と称せられている振動棒へ の検液の附着に原因する rod の有效質量の增大す る結果が出て的ると解积できる。

(1)式飞示されるように, shape factor $a^{\prime}$ は 環状空間 (annular space) の大きさの函数であつ $\tau$, 内径 $\left(\operatorname{rod}\right.$ の径 $r_{\imath}$ ) を固定するとを, 外径 (cap の径 $\left.\boldsymbol{r}_{a}\right)$ の函数である. Fig. 8 は, $r_{i}=0.15 \mathrm{~cm}$ として，ra 在変化させをときの $(1)$ 式による計 算值(実線)ならびて測定值を示したものである。 理論值では $r_{a}$ 無限大で零に湢近するが, 実㵋値 では $0.5 \mathrm{~cm}$ 上上で恒数 1.2 亿漸近する. 以下 $r_{a}$ の大きい值での測定值て和いての shape factor は $a^{\prime}=1.2$ として計算した。

当装置を用いて鋳込特性を測定するとは，振動 棒を Fig. 9. 亿示すように鋳型中に, 鋳型面より 一定距離 $d$ ゲけ離して設置する。鋳込の進行とと もと，鋳込体は厚さを増して行くが，乙の際，固 化した壁である鋳込体が振動棒の一つの侧から近 づレてきて, 鋳込体の厚さが充分厚くなつた時, 振動 棒は鋳込体で包まれる。したがつて, 初めと終りの状 態を除く途中の状態では, 測定值は厳密な粘弹性係数 を与光ない. Fig. 10.はこの壁の近づく影響をグリセ リンで検した結果である。との結果より，壁が $\operatorname{rod} の$ 近傍 $1 \mathrm{~mm}$ 以内にあれば壁の影響を受けるが, $1 \mathrm{~mm}$ 以上離れて秃れば壁の影響はならとと，叔よ゙ $1 \mathrm{~mm}$ 以内和々てもその影響は大をくて倍の orderである ととが判る。

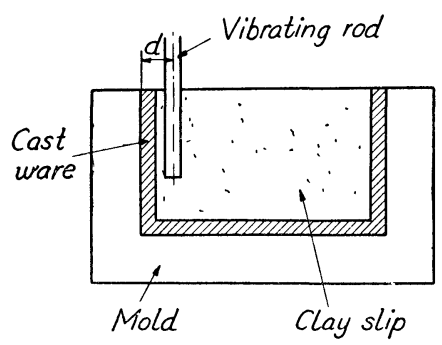

Fig. 9.

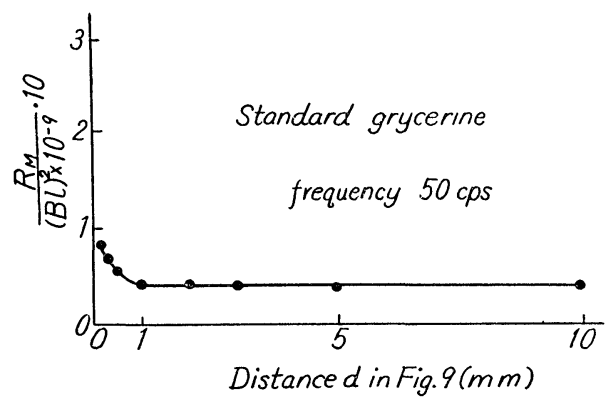

Fig. 10. Relation between $R_{M}$ and the distance $d$ in Fig. 9 .

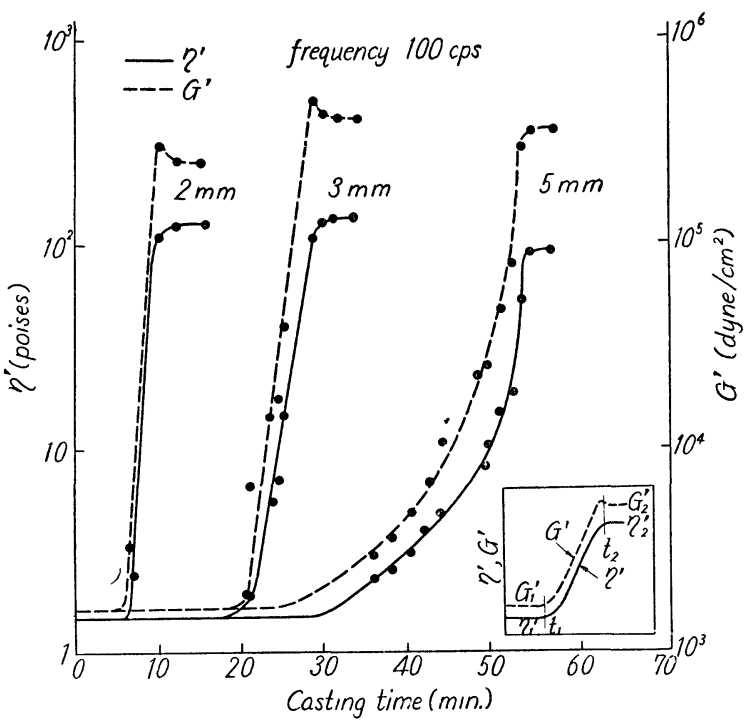

Fig. 11. Change in the dynamic properties $\left(\eta^{\prime}, G^{\prime}\right)$ during the casting prosess.

鋳込特性の測定のために用いた鋳型の大きさは， $90 \times 90 \times 70 \mathrm{~mm}$ の外形の中に $33 \times 33 \times 45 \mathrm{~mm}$ の直方 形の内孔部を有する。試料泥漿は木節占土 40 , 蛨石質 骨材 40 , シャモット質骨材 20 を珪酸ソーダで解廖さ せたガラス愹融坩堝用坏土である。Fig. 11 は，鋳型 の型面と測定棒との距離 (Fig. 9 の ) 要 $2,3,5 \mathrm{~mm}$ に変えて測定した結果である。

$\eta_{1}{ }^{\prime}, G_{1}{ }^{\prime}$, は最初の泥漿の特性であるが, 鋳込が進行 して固化した壁である鋳込体が，振動棒の近旁に到達 すると(時間 $t_{1}$ て和いて)， ク'も $\eta^{\prime}$ も上昇を始める. この上昇は振動棒が鋳込体である坏土で包まれてしま うと $\left(t_{2}\right.$ て和々て), 坏土に相当した $\eta_{2}{ }^{\prime}, G_{2}{ }^{\prime}$ を示す. $\eta_{1}{ }^{\prime} ， G_{1}{ }^{\prime}$ から $\eta_{2}{ }^{\prime} ， G_{2}^{\prime}$ 亿至る間は, 図の例では指数函 数的に示されるが，乙の間では前記のようて厳密な粘 弾性係数を示さならので, 変化の形から鋳込特性を特 徵づけることはできない. 鋳込特性を表現する值とし ては，(1) $t_{1}$ の大きさ，(2) $t_{2}-t_{1}$ の大きさ，(3) $\eta_{2}{ }^{\prime}, G_{2}^{\prime}$ の大きさ, (4) $\left(t_{2}-t_{1}\right) /\left(G_{2}{ }^{\prime}-G_{1}{ }^{2}\right)$ あるい は $\left(t_{2}-t_{1}\right) /\left(\eta_{2}^{\prime}-\eta_{1}^{\prime}\right)$ などの值が考えられる。

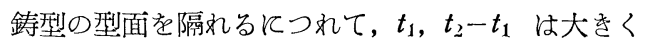
なる、 埌 は小さくなる傾向にあり，鋳込体は壁を隔 れるにつれて軟くなるととを示している， $G_{2}{ }^{\prime}$ は $t_{2}$ で らつたん極大を示して, その後で少し低下する傾向を 示す. $\left(t_{2}-t_{1}\right) /\left(\eta_{2}{ }^{\prime}-\eta_{1}{ }^{2}\right)\left[\right.$ あるいは $\left.\left(t_{2}-t_{1}\right) /\left(G_{2}{ }^{\prime}-G_{1}{ }^{\prime}\right)\right]$ の值は，壁をはなれるにしたがつて大きくなる。鋳込 体が型面に接する部分で硬さの大きいのは, 型面に近 らほざ早く構成されて, 石嵉による脱水の効果を受け るために硬いのでなくて，鋳込体が構成される瞬間に おける硬さも壁を隔れるにつれて低々. Table 1 は 
Table 1.

\begin{tabular}{c|c|c|c|c}
\hline Sample & $\begin{array}{c}d \\
\mathrm{~mm}\end{array}$ & $\begin{array}{c}\text { Casting } \\
\text { time } \\
\text { min. }\end{array}$ & $\begin{array}{c}\text { Retained } \\
\text { water } \\
\%\end{array}$ & $\begin{array}{c}\text { Linear } \\
\text { shrinkage } \\
\%\end{array}$ \\
\hline No. 1 & 5 & 55 & $19 \cdot 9$ & $5 \cdot 2,4 \cdot 79$ \\
No. 2 & 3 & 31 & $18 \cdot 9$ & $4 \cdot 71,4 \cdot 89$ \\
No. 3 & 2 & 13 & $17 \cdot 6$ & $4 \cdot 36,-$ \\
\hline
\end{tabular}

Fig. 11 の利の抋のの試料につ々て, 鋳込体の保有水 分と乾燥収縮を測定した結果であるが，上記の結論の よい裏付となつていると思う。

振動经によつて鋳込特性を測定するには, 硬化体で ある鋳込体を振動によつて摆乱しながら測定するの で，との意味でも㛜密な值を示さない扣とれがある。 しかし, 上記のようにして比較的な值として鋳込操作 中の硬化の模様を推定することができた。

\section{4. 総括}

振動法によつて動粘性, 動弾性保数を測定する方法 を用らて, 鋳型中で鋳込体が構成されて行く模様の推 定を行つた。 その結果, 泥獎から坏土になるにつれて $\eta^{\prime}$ \& $G^{\prime}$ も高的值となる。そのなり方は型面を離れる につれて要する時間が大をくなりできる鋳込体も

“soft”になるなとのととを結論した。

鋳込特性飞影響する変数としては, ( 1 )泥漿の濃度, (2)泥漿の解膠度, (3) 用いた解膠抄の種類, (4)泥 漿中の固体分中の粘土分, (5)固体分の粒度分布,

(7)温度などがあり, また, その結果として表われる (8)摇変性なぞがある. 次の㙨会には, これらの因子 が鋳込特性に及市影響について考察を行ら予定であ
る。さらに以上の測定はすべて流動鋳込についてであ つたが,固形铸込についても同様少測定が可能であり, それらについても別に報告する。

当測定に用的音声域発振器の検定については, 京 大, 工研, 西朋太助教授の御好意と御指導によつた。 厚く御礼を申し上げなす。

注: 一

1) A.L. Johnson, F.H. Norton, J. Amer. Cer. Soc,, 25, 337 (1942)

2）茂木, 武田, 日立平論, 32 (1950)

3）秦木, 篦協, 59, 96 (1951) 外多数

4) R.G. Graham, J.D. Sullivan, J. Amer. Cer. Soc., 18, 97 (1939)

5) W.D. Kingery, J. Francl, J. Amer. Cer. Soc., 37, 596 (1954)

6) G.W. Phelps, J.G. Woodward, S.G. Magurie, J. Amer. Cer. Soc., 36, 60 (1953)

7) J.G. Woodward, Amer, Cer. Bull., 31, 389 (1952)

8) J.G. Woodward, Electronics, 25, 98 (1952)

9) J.G. Woodward, J. Colloid Sci., (1 151$)$

10）素木氏は高濃度泥獎について集静的に粘性と弹性を則定してい る, 䈍協, 63, 194 (1955)

11) T.L. Smith, J.D. Ferry, F.W. Scheremp, J. Appl. Phys., 20, 144 (1949)

12）Ferry の装置は堀尾氏，小野木氏[化学々工業，5, 577 (1952)] により,また, 村上化〔㭁料試脸, 3,186 (1954)]により紹介実 用されている。

13) J.D. Ferry, W.M. Sawyer, J.N. Ashworth, J. Poly. Sci., 2, 593 (1947)

14) R.D. Andereus, Ind. Eng. Chem., 44, 707 (1552)

15) W. Philippoff, J. Appl. Phys., 25, 1102 (1954)

16) J.J. Bikermann, J. Coll. Sci., 3, 73 (1948)

17) J.T. Beiger, W. Pattersen, J. Appl. Phys., 24, 712 (1593)

18) H. Markovitz, J. Appl. Phys., 23, 1070 (1ฐ52)

19) H. Leaderman, J. Coll. Sci., 4, 193 (1949)

20) A.W. Nolle, J. Poly. Sci., 5, 1 (1950)

21) M.L. Sheely, Ind. Eng. Chem., 24, 1050 (1932)

\section{Tread type 防振ゴムのクリープについて*}

$$
\text { 椹木義一**谷口肇彥***古市稔*** }
$$

\section{On the Creep of Rubber Vibration Absorber of Tread Type \\ Yoshikazu Sawaragi, Toshihiko Taniguchi and Minoru Furuichi}

In the creep of rubber vibration absorber of Tread type, we recognized experimentally the existence of virgin curve and found the creep strain was not proportional to the stress at a certain time after loading. These phenomena are explained reasonably by the dynamical model proposed by Sawaragi and Tokumaru for nonlinear viscoelastic bodies. In practice, it is not desirable to use these materials in the state in which virgin curve will be obtained, for then the permanent set from internal solid friction results. In order to make these materials useful in practice, we must get them to creep to a certain degree and to recover enough. Then we can get the stable state of these materials. In this report a suitable load and the duration time of load to give such a stable state are estimated.

\footnotetext{
* 原稿受付 昭和 30 年 5 月11日

** 正員 京都大学工学部

*心决京都大学工学部大学㗂学生
}

\section{1. 緒言}

粘弾性体のクリープ現象には, カーボンブラックを 含まない加硫ゴんのよらに, Fig. 1飞みるVoigt要素 